\title{
Aldo MAGRIS (a cura di), Il manicheismo. Antologia dei testi, Vago di Lavagno 2000, Morcelliana, ss. 396.
}

Na włoskim rynku wydawniczym pojawiła się niedawno antologia tekstów manichejskich. Zasługuje ona tym bardziej na uwagę, że jest to pierwsza tego typu praca skierowana do włoskiego czytelnika. Redaktorem wydania jest Aldo Magris - profesor przy Katedrze Filozofii Religii w Trieście. Manicheizm był jednym z najbardziej znaczących heterodoksyjnych kierunków religijnych epoki starożytnej. Przez ponad tysiąc lat jego zwolennicy rozszerzali swoją naukę o zbawieniu na szerokim obszarze, poczynając od terenów nad Morzem Śródziemnym, poprzez Mezopotamię, Iran, Jedwabny Szlak, a kończąc na Azji centralnej i Chinach. System religijny stworzony przez Maniego w III wieku po Chrystusie, stanowił oryginalną syntezę apokaliptycznego judaizmu i chrześcijaństwa $z$ wpływami mitów i doktryny gnostyckiej, a także elementów zaczerpniętych z zoroastryzmu irańskiego i buddyzmu. Pisma manichejskie powstawały głównie w języku perskim, partyjskim, koptyjskim, greckim i chińskim. Próba przybliżenia oryginalnych treści manichejskich w języku włoskim może stanowić znaczący wkład do bezstronnego, nieskażonego polemicznym nastawieniem, poznania manichejskiej doktryny. W jaki sposób profesor Magris postarał się nam to umożliwić?

Prezentację tekstów manichejskich A. Magris poprzedził wstępem (s. 742), w którym przedstawił życie i działalność Maniego. Najpierw ukazał wpływ środowiska intelektualnego oraz sytuacji politycznej na proces kształtowania świadomości religijnej Założyciela (s. 8-14). Wspomniał też o przyjaźni łączącej Maniego z królem Szapurem (s. 15-16). W wyniku sprzyjającej sytuacji Mani rozpoczął liczne podróże misyjne, czy to sam, czy to wysyłając swoich misjonarzy: Indie, Afganistan, Turkiestan i Chiny, Syria, Palestyna, Aleksandria, Egipt środkowy, północna Afryka (s. 17-21). Jednak działalność Maniego, prócz sukcesów, naznaczona była także cierpieniem. Po śmierci bowiem Szapura $(† 272)$ oraz jego starszego syna Hormizdasa ( $† 273)$, przejął władzę młodszy syn Bahram, który, będąc wyznawcą mazdaizmu, ostro wystąpił przeciwko Maniemu. Założyciel, wtrącony do więzienia, umarł tam z wycieńczenia 26 lutego 277 roku. (s. 21-23). W dalszej części wprowadzenia A. Magris przedstawia dzieje manicheizmu od śmierci Założyciela aż do XV wieku, kiedy jeszcze w Turcji i Chinach wspominano o istnieniu wspólnot manichejskich (s. 23-27). Przybliżył także przy tym czytelnikom stan edycji źródeł manichejskich; podkreślił znaczenie stosunkowo niedawno odkrytych oryginalnych pism w okolicach Turfan (Chiny) oraz Medinet Madi (Egipt), zauważając, iż doktryna Maniego została wyrażona również w tekstach polemistów (Augustyn z Hippony, Tytus z Bosry, Efrem z Nissibis) (s. 28-31). Autor przedstawił także w skrócie główne założenia systemu manichejskiego: kosmologiczne, soteriologiczne, eschatologiczne (s. 32-40), wymieniając na końcu 
nazwiska tłumaczy i współpracowników, którzy przyczynili się do powstania niniejszego opracowania (s. 40-42).

Zawarte w Antologii teksty zostały podzielone na 5 rozdziałów według kryterium tematycznego o przejrzystej strukturze. W rozdziale I (s. 51-115) znajdują się teksty o życiu Maniego. Zostały one umieszczone w kolejności chronologicznej tzn. przedstawiającej poszczególne etapy życia Manesa. Tekst I: „Młody Mani i sekta Elkazaitów” (s. 51-88); tekst II: „Mani w Indiach; nawrócenie króla Toghranu” (s. 89-90); tekst III: „Nawrócenie księcia Messeny” (s. 91-92); tekst IV: „Mani jako dopełnienie Objawienia”(94-105); tekst V: „Aresztowanie i śmierć Maniego” (s. 108-115).

W rozdziale II (s. 119-131) zawarte zostały teksty ilustrujące niektóre wydarzenia z historii Kościoła manichejskiego: „Struktura Kościoła manichejskiego” (s. 119-121); „Kościół według koncepcji Maniego” (s. 123-124); „Misje Addady na Zachodzie i Ammosa na Wschodzie" (s. 125-131).

Rozdział III (s. 134-209) zawiera pisma, które przybliżają fragmenty podstawowych mitów manichejskich: „Atak Ciemności i działanie Posłanych” (s. 135-137); „Pierwszy Posłany i walka pierwotna” (s. 139-150); „Drugi Posłany i Drugie Stworzenie” (s. 151-165); „Trzeci Posłany i stworzenie człowieka” (s. 167-192); „Symbolika słońca” (s. 193-194); „Astrologia manichejska” (s. 195-205); „Ostatni Bóg” (s. 207-209).

Zbiór pism umieszczonych w rozdziale IV (s. 213-291) A. Magris opatrzył tytułem „Teksty doktrynalne”. Znajdujemy tam utwory ilustrujące następujące elementy doktryny manichejskiej: „Dualizm duszy i ciała” (s. 213-215); „Przemiana czlowieka starego w człowieka nowego" (s. 217-247); „Z formularza modlitw i wyznania dla Wybranych” (s. 249-266); „Życie moralne Manichejczyków” (s. 267-282); „Eschatologia indywidualna” (s. 283-290); „Sąd ostateczny z Traktatu dla Szapura" (s. 291).

W ostatnim, V rozdziale A. Magris umieścił wybór manichejskich tekstów liturgicznych: „Dialog Jezusa z Dzieciątkiem” (s. 295-297); „Wielkie hymny partyjskie” (s. 298-315); „Hymny do Jezusa” (s. 317-352); „Hymny do trzeciego Posłanego” (s. 353-355); „Hymny do duszy żyjącej” (s. 358-363); „Hymny Paranirvany” (s. 365-370); „Florilegium modlitw” (s. 371-374).

W suplemencie Autor umieścił terminy określające „pięć części duszy w doktrynie manichejskiej" w językach, w których nauka Maniego została spisana. (s. 375-378). Redaktor dołączył także wykaz użytych w Antologii fragmentów pochodzenia środkowo-irańskiego i koptyjskiego (s. 379-380). W celu łatwiejszego wyszukania poszczególnych osób czy tematów A. Magris umieścił w zakończeniu trzy indeksy: imion starożytnych, imion nowożytnych oraz terminów teologii manichejskiej (s. 383-392).

Należy zauważyć, iż zastosowany w pracy przejrzysty podział tematyczny umożliwia czytelnikowi zapoznanie się z interesującym go materiałem. Każdy $z$ rozdziałów został opatrzony krótkim wstępem, który ułatwia nawet niezbyt 
przygotowanemu merytorycznie czytelnikowi zapoznanie się ze skomplikowaną terminologią i treścią manichejskiej doktryny. Podobną rolę w tekstach pełnią także komentarze zawarte w przypisach. Charakterystyczne dla doktryny manichejskiej terminy zostały umieszczone w oryginale (transkrypcja fonetyczna). Należy także docenić fakt, iż Redaktor wybrał teksty z wszystkich dostępnych na dzień dzisiejszy wydań manichejskich pism.

Jednak, jak każda antologia, tak i niniejsza praca stanowi subiektywny wybór autora. Wśród wykorzystanych dzieł przeważają teksty znalezione w Turfan. Szkoda, że Autor nie przybliżył w większym stopniu manichejskich tekstów zachowanych w języku koptyjskim, jak choćby Psalmy Bema. W zbiorze Hymnów do Jezusa (s. 317-352) Redaktor umieścil także Psalmy Heraklidesa (s. 321-334), które w A Manichean Psalm-book, part II C.R.C. Allberry (s. 97) znajdują się w innym zbiorze psalmów. Charakter naukowy zbioru obniża także brak tekstów oryginalnych. Należy jednak stwierdzić, iż niniejsza antologia spełnia zamierzony przez Redaktora cel; przybliża zainteresowanym historię, terminologię, doktrynę dogmatyczną oraz przepisy moralne i liturgiczne Manichejczyków. Oby podobna praca mogła wkrótce ukazać się również na polskim rynku wydawniczym.

Ks. Roman Szmurło - Warszawa, UKSW

\section{Costituzioni dei Santi Apostoli per mano di Clemente, trad. Domenico Spada - Dimitrios Salachas, Roma 2001, ss. 316.}

W Wydawnictwie Urbaniana University Press ukazały się po raz pierwszy w języku włoskim Konstytucje Apostolskie. Tłumaczenie tego najważniejszego i najbardziej kompletnego tekstu legislacyjnego pierwotnego Kościoła oparte zostało przede wszystkim na wydaniu F.X. Funka (Paderborn 1905), w pracy korzystano jednak również z wydania francuskiego M. Metzgera (Paryż 19851987).

W obszernym Wprowadzeniu do Konstytucji, autorzy tłumaczenia ukazali strukturę tego dzieła, środowisko, w którym powstało, oraz jego charakter literacki. Wyszczególniono także wszystkie istniejące manuskrypty i ukazano historie poszczególnych wydań. Na końcu książki zamieszczono, w kolejności, następujące indeksy: cytatów biblijnych, tematyczny, terminów kanonicznych, oraz obszerną bibliografię. Tłumaczenie jest owocem współpracy pomiędzy Wydziałem Teologii i Wydziałem Prawa Kanonicznego Papieskiego Uniwersytetu „Urbanianum”, a autorami są jego profesorowie: Domenico Spada i Dimitrios Salachas.

Jeżeli chodzi o samo dzieło - Konstytucje Apostolskie, to odzwierciedlają one zasadniczo tradycje Kościołów Syrii i Antiochii, a pośrednio także tradycje całego 